\title{
"I show you my coast..."-a relational study of coastscapes in the North Frisian Wadden Sea
}

\author{
Martin Döring $^{1} \mathbb{D} \cdot$ Beate Ratter $^{1}$
}

Received: 13 October 2020 / Accepted: 6 August 2021 / Published online: 17 September 2021

(c) The Author(s) 2021

\begin{abstract}
In recent years, there has been an upsurge in research on relational approaches in geography and in the study of cultural landscapes. Following these strands of research, the relationality of human beings with their natural environments has been highlighted, emphasising the various ways people engage with their lifeworlds. This development is motivated by the perceived need to analytically expand landscape research towards a more-than-representational point of view, challenging the still prevalent dichotomy of nature and culture. The paper takes these insights as a starting point and provides an insight into a more-than-representational understanding of coastscapes that is combined with a more-than-representational understanding of language. Its aim is threefold: to theoretically engage with a more-than-representational and enlanguaged understanding of coastscapes; to explore the relevance of mobile methods for such an approach; and to empirically illustrate the emotive and relational bonds coastal dwellers form with their littoral environs. To capture the dynamism of a more-than-representational understanding that coastal dwellers develop with their coastscape, walking interviews were conducted in the district of North Frisia (Germany). All interviews were examined following a grounded approach and refined by a linguistic in-depth investigation. The analysis revealed four prevailing interpretative repertoires reconfiguring the boundary between nature and culture. They exhibit what we call a coast-multiple that adds to coastal nature-society-mixes which might be of interest for future coastal management at the German Wadden Sea.
\end{abstract}

Keywords Coastal landscapes · More-than-representational theories $\cdot$ Ecolinguistics $\cdot$ Walking interviews $\cdot$ German Wadden Sea $\cdot$ Northern Frisia

\section{Introduction}

Human beings form multifaceted relationships with the physical environments they inhabit. Places, cities, gardens, pastures, parks or landscapes are suffused with human-environment relations (Stenseke 2018). This also applies to coastscapes whose sometimes extreme (Ryan 2012), transient (deSilvey 2012) and liminal characteristics (Leyshon 2018) contribute to the development of dynamic human-coast relations. Coastscapes are understood as the realm "shaped" (scape) by human (embodied, material and mental) and natural action. Coastal landscapes are neither

Martin Döring

Doering@metaphorik.de

Beate Ratter

beate.ratter@uni-hamburg.de

1 Institute of Geography, University of Hamburg,

Bundesstraße 55, 20146 Hamburg, Germany exclusively of the land nor the sea, but materially reside in the in-between, and those who live in and with them are often challenged by the variability and dynamics of their coastal surroundings (Holzhausen and Grecksch 2021). Even more, the experience of the coast with its dynamics seems to challenge the dualism of land and sea and opens up the comprehensiveness of spatial experiences rendering the separation between nature $=$ sea $/$ shore and culture $=$ coastal landscape worthy of discussion (Castree 2005; 2014). This, in particular, applies to dwelt-in (Ingold 2000) coastal landscapes in which the affective, felt and emotional (Pile 2010) sensibilities of its inhabitants are entangled with its materiality and exhibit various dimensions and ways of how individuals or groups are immersed in their coastscape. Hence, coastscapes and their inhabitants are networked (Latour 2007) into each other constituting variable human-environment relationships revolving around what one generically calls the coast. 
Comparable aspects have also been addressed in research on cultural landscapes. This field of research conceptually distinguishes between the entity of the land - to be understood as referring to the so-called natural and tangible features of the materiel landscape - and the notion of landscape which refers to its symbolic and/or intangible characteristics (Bender 1993). This dichotomy represents a heuristic differentiation that does not aim to draw a veil over the integrated and intertwined dimensions of land and landscape (Robertson and Richards 2003: (1) on the contrary, it refers to different theories and approaches in landscape research which emerged during the past decades (Wylie 2007; Howard et al. 2019) originating from various disciplines such as geography, architecture, literary studies, anthropology, spatial planning, literary studies, ecology, art history, etc. (Vincenzotti et al. 2016). Within this field of research, studies on coastscapes emerged over the past two decades investigating the historical, social, political, economic or cultural dimensions of coasts (Corbin 1995; Lençek and Bosker 1999; Döring et al. 2005; Pearson 2006; Land 2007; Gillis 2014; Worthington 2017; Leyshon 2018; Walsh and Döring 2018; Ratter and Walsh 2019; Walsh 2020). One part of this type of research engages with coastscapes within the context of a growing scientific awareness about a looming climate change (Brace and Geoghegan 2010; Köpsel et al. 2017) and connected threats such as sea-level rise (deSilvey 2012). The insights provided here are reactions to scientifically informed ways of doing coastal management and call for integrated and participative ways in which the study of coastsapes holds the potential to provide valuable insights into its socio-cultural dimensions of coasts. Such aspects have also been addressed in a variety of publications dealing with coastscapes such as Boissevain and Selwyn (2004), Visser (2004), Gillis (2014), Ryan (2012), Gesing (2016), Köpsel et al. (2017), Egberts and Schoor (2018), Walsh and Döring (2018), Ratter and Walsh (2019) or Ratter and Leyshon (2021). Here, landscaperelated theories and their application in various contexts have provided first ideas of how to reconnect scientific and social research on the coast. These attempts have recently been complemented by more-than-representational and relational approaches in research on coastscapes (Ryan 2012; Vannini and Taggart 2012; Gesing 2016; Döring and Ratter 2018; Ritson 2018 and Walsh 2018 and 2020) that theoretically and empirically aim at enhancing research undertaken by emphasising the lifeworld aspects of coasts with their manifold social, relational and emotive dimensions. They call for a more comprehensive and experience-based understanding of the coast because foreshores have always been spaces and places of social practice weaving coastal natures and cultures together (Ingold 2000: 192). Coastscapes could hence be understood as the materiel outcome of human and non-human coevolution comprising ecological, social, economic and institutional aspects as well as values, aesthetics, knowledge and traditions implicated in the coast (Stenseke 2018: 84). In short, coasts represent a relational livelihood (Ingold 2000: 9-12) through which individuals, communities, social groups, institutions, science and societies reproduce and experience themselves (Matless 2001: 73-95).

Based on these preliminary considerations, the present paper empirically explores the coastscapes of the North Frisian Wadden Sea from a more-than-representational and relational point of view. It uncovers the sensuous and sensible relations (Rodaway 1994) local people form with their coastal environments and analyse how they structure their relationship with their coast. The paper starts in the following section with conceptual issues revolving around the theoretical foundations of a more-than-representational understanding of coastscapes that includes language as an important structuring and analytical unit. It then depicts and explains the rationale of our mobile method-walking interviews - for investigating coastal landscapes. After that, the empirical analysis and interpretation of paradigmatic examples taken from our data will show how deeply local people are enmeshed (Ingold 2008) with their littoral environments. The final section will summarise the results, reflect on the methods applied and reconsider theoretical issues. Furthermore, it will-though tentatively - muse on the potentials a more-than-representational understanding of coastal landscapes holds for coastal management.

\section{More-than-representational coastscapes: seeing, embodying and articulating the littoral}

A closer look at research undertaken in the field of landscape studies (Wylie 2007; Howard et al. 2019) shows that a variety of methods and theories has been developed over the past five decades that span a continuum from iconographic or symbolic approaches (Cosgrove and Daniels 1988; Cosgrove 1988; Warnke 2004) to more recent interpretations of landscapes in terms of relational or more-than-representational approaches (Wylie 2002; 2005). The latter developed in reaction to the prevalent framing of landscapes as text analysing past and current social meanings to be read off or decoded from landscape. The conceptual emphasis of this approach on seeing and reading with its concomitant notion of representation and cognition has-according to Thrift (2000: 380) -led attention away from the small (Hasse 2017) but constitutive little things that happen when people engage with spaces, places and landscapes (Macpherson 2006). Comparable criticism has also been addressed in Tim Ingold's work with his dwelling approach to landscape (Ingold 2000: 157-171). Land and landscapes, from this perspective, are drawn together and regarded as a dwelt-in 
milieu of involvement (Wylie 2007: 161-162) going beyond the dichotomy of nature and culture. Any act of representing a landscape is, following his understanding, a practice actively taking place in a landscape (Seamon 2018) and not a ready-made representation of landscape in people's minds (Anderson and Harrison 2010). Referring to this line of thinking, non-representational (Thrift 2007) or-positively expressed-more-than-representational approaches (Lorimer 2005) to landscape emphasise the body and practices as experiential sites and means for knowledge production (Wylie 2007: 162-166) because "everyday physical surroundings demand bodily immersive, ingressive and visceral engagements" (Ryan 2012: 5). Representations are still conceived as important analytical and heuristic elements, but their prevalence in research has attracted too much attention (Dewsbury 2003: 1910) resulting in the fact that many scholars lost sight of the important dimensions of "corporeal" thinking (Thrift 2004: 67). It is consequently not only human cognition that connects individual and landscape, but also corporal affects, feelings and emotions play a vital role in inspiring and structuring this interrelationship (Dewsbury et al. 2002: 439). Hence, landscapes should theoretically be understood as "lived, embodied and tangled up with how we do things-our doings, interactions and enactments [...]" (Waterton 2019: 92). This embodied conversation (Harrison 2000) draws landscape, body and the mind into one and situated network: the body dwells in landscapes and places and landscape and places reside in the body (Basso 1996; Mels and Setten 2007; Macpherson 2010).

Comparable aspects have also been outlined in research on coastal landscapes (Hansen 2021). Many studies conceive coastal landscapes or coastscapes as dynamic and interactive sites resulting from natural and social processes and theoretically examine them with the help of a historical perspective (Corbin 1995; Gillis 2014 or against the conceptual backdrop of textual rationales (Fischer 1997; Döring et al. 2005; Fischer et al. 2007). These approaches have been complemented by studies that further the textual rationale in the direction of more-than-representational understandings of the coast (Ryan 2012; Gillis 2014; Hasse 2014, 2016, 2017; Wylie 2005; Gesing 2016; Döring and Ratter 2018; Leyshon 2018; Walsh 2018; Walsh 2020; 2021) that invite further conceptual reflections since the dynamic physical state of coastscapes impede clear spatial categorisation to sea or land. Even more, the meeting of the land and the sea gives "...rise to specific and strong sensibilities of texture and materiality" (Ryan 2012: 12). Hence-beyond the pure/ simple shaping/doing of land-specific visual, tactile, olfactory, audible, temporal, weathered (Hulme 2016), geological, biological affordances (Gibson 1979) become experientially embodied in the individuals emplaced in their littoral environs (Pearson 2006).
Taking these aspects of a more-than-representational and relational perspective on coastscapes into consideration, we seek to further the more-than-representational approach by focusing on how the coast is linguistically articulated. The verb to articulate is deliberately used here as its etymology refers to the Latin word articulus meaning joint. We, therefore, analytically raise the issue that language plays a vital role in joining and representing the various experiences made in coastal landscapes. These articulations, to be understood as one type of practice, characterise the enlanguaging (Love 2017) of the coast and are an analytical unit through which different kinds of individual relations to and collective representations of coastscapes can be investigated. Language is, following such an understanding, not envisaged as a "self-contained independent mental organ" representing (Harré et al. 1999: 1) the outside world, it is rather conceived as an embodied and situated process (Johnson 1987) that builds meaningful and relational patterns exhibiting, in our case, enlanguaged "acts of landscaping" (Lorimer 2005: 8). Such an enactivist conception of language (Hutton 2013) contradicts more mainstream approaches in linguistics that conceive language as an autonomous brain-based system separate from both language users and their environments (Varela et al. 1991: 1). We hence follow an experience-based (Lakoff and Johnson 1980; Johnson 1987) and enactivist approach to language and meaning that avoids the traps of a traditional system-view (Steffensen and Fill 2014) and puts emphasis on what people actually do with language (Steffensen 2009) in places and landscapes.

This return to the so-called talking, practice and performative side in linguistics converges with the interactive rationale of more-than-representative approaches in research on landscape and is grounded in a Wittgensteinian (Wittgenstein 2009) understanding of language games as expressed by Thrift (1999). Language games are conceived as performative, situated and practice-based speech acts that develop into commonly understood forms of life (Wittgenstein 2009: §19) resulting from distributed languaging (Cowley 2011, 2019). Language is understood as an emplaced social process based on situated language games. This analytical approach investigates how nature and culture are meaningfully interlaced through co-existence and interactivity (Bang and Trampe 2014). Such an emphasises on meaning as resulting from situated speech acts (Austin 1962) or the contextualised use of language (Wittgenstein 2009: §23) and not exclusively from thinking, opens-up a perspective that allows to focus on the vital, sensitive, felt and emotive articulations of the coast (Medby 2019:2). Meanings lie in knowledge about the rules of language games (Wittgenstein 2009: §83) and these language games- to be understood as dynamic gestalts that emerge and alter as we go along in spaces, places and landscapes (Wittgenstein 2009: §83)—are 
built by structural elements such as pronouns, nouns, adjectives or metaphors and the like.

Such a "not-in-the-head-understanding" of language (Süsswein and Racine 2009) holds strong conceptual links with more-than-representational and relational approaches to landscape (MacPherson 2010) and place (Medby 2019) as also expressed in Thrift's ecology of place: "Non-representational theory arises from the simple [...] observation that we cannot extract a representation of the world from the world because we are slap bang in the middle of it [...] We act to think, and we only think we think to act because we have let some quite specific forms of life colonize our notion of what constitutes [...] [landscape]" (Thrift 1999: 296-297). In sum, enlanguaged meanings are interactive and place-based processes of situated language games that interlace coastal dwellers and their dwelt-in coastscapes, while the ecology of place puts emphasis on how places like coastscapes are shaped and articulated through the social practice of language games. Such a vitalist (Hasse 2017: 44) and re-animated (Rose and Wylie 2006) understanding of enlanguaged and emplaced coastscapes requires an experience-based method to systematically analyse how the North Frisian coast is articulated.

\section{"Let's go, I show you my coast": mobile methods revealing a more-than-representational coastscape of North Frisia}

A more-than-representational and relational understanding of land- and coastscapes, which considers the situated and enlanguaged human dimensions, requires a method that enables an emplaced collection of data to capture their interactive and vital creation (Vannini 2015; King and Woodroffe 2017). This has led us to conclude that the method of walking interviews (Kusenbach 2004; O'Neil and Roberts 2019; Spinggay and Truman 2019; Liburd et al. this volume) is a theoretically and methodologically sound way to generate data for our more-than-representational and relational purposes. Walking interviews offer the possibility to witness, collect and analyse the emplaced interaction between coastscapes and the interviewee, provide the opportunity to share embodied and spatial experiences of the landscape (Anderson and Harrison 2010) and can assist in developing more accurate interpretations of the data gathered. In brief, the rationale of this method - to be understood as only one part of the "new mobilities paradigm" (Sheller and Urry 2006: 226) - highlights the interactions to be performed between the coastscape and the interview partner (MacPherson 2016).

It is for this immediacy and intimacy between the interviewee and the landscape that walking or go-along interviews have been depicted as a "wonderful way of gathering data" (Moles 2008: 2) because they are supposed to lead to "naturally occurring conversation[s]" (Jones et al. 2008) generating thick data of emplaced interactions. This enthusiasm about mobile methods in general and walking interviews in particular has to be treated with care as mobile methods do not per se contribute to generating better or purer data. On the contrary, the setting of a walking interview has its own cultural conditions, constraints and limits. The social practices of walking (Gros 2011), for example, do not only bear an impact on the relation between interviewee and interviewer in the course of the interview, but also characterise the data generated in specific ways (MacPherson 2016). The basic advantage of walking interviews, however, consists in the important aspect that the emplaced, embodied and mobile interview setting uses the surrounding landscapes and places as a key stimulus, leading to data only partially attributable to the interview questions themselves. These aspects are complemented by the aspect that walking interviews create the opportunity and enable the formation of vital resonances with the present landscape (Hasse 2017: 44). The multiplicity of these sensible and sensitive elements occurring in the interview setting is fascinating, requires attention on the side of the interviewer (Hasse 2017: 62) and helps her to become attentive to, reveal and analyse the associative implication complexes (Black 1993) by which human beings immerse themselves into their landscapes. In sum, walking interviews as a method meet in our opinion the methodological requirements of a more-than-representational approach.

Yet, to more accurately open up the multi-layered human and intertwined dimensions nestling in the coastscape, we aimed at enhancing the approach of walking interviews by taking a close look at the language games used during the walks. This means that all interview trails were chosen by the interviewees themselves who showed the interviewer their preferred coastal environs. After each interview, maps of the enwalked places were plotted to replicated the routes taken and to retain specific places or elements in the landscape as enlanguaged or highlighted by the interviewee. These maps were complemented by ad hoc protocols written directly after the interview in which specific practices of the interviewee in the landscape or linguistic aspects during the course of the interviews were noted down. They assisted in the ensuing analysis of the interviews. ${ }^{1}$

To capture and systematise the complexity of the data generated, we applied the analytical concept of interpretative

\footnotetext{
1 The roles of the interviewer as novice of, companion in, questioner about and recorder of the ongoing landscaping and that of the interviewee as companion and local landscape connoisseur were also reflected upon throughout the analysis.
} 
repertoires to our interview transcripts. They are conceived as language games and interactively generated meaning structures that exhibit more or less " $[\ldots]$ internally consistent, bounded language units [...]" (Whetherell and Potter 1988:171). Interpretative repertoires are seen "[...] as building blocks speakers use for constructing versions of actions, cognitive processes and other phenomena [such as coastscapes]. Any particular repertoire is constructed out of a restricted range of terms [...]" (Whetherell and Potter 1988:172). These conceptual insights were coupled with a Grounded Analysis (Corbin and Strauss 2015) of the interviews which helped us to categorise the data gathered. After this step, each inductive category developed was re-analysed in view of a systematic linguistic study dissecting characteristic structures and interpreting them with the help of the maps and protocols produced. This procedure assisted in re-emplacing the linguistic elements occurring in the categories and helped in interpreting them. If there was sufficient linguistic consistency in terms of shared metaphors, nouns, adjective and phrases etc. used, the previous category was transferred into an interpretative repertoire which then was conceived as an enwalked and enlanguaged language game. All in all, 12 interpretative repertoires were found, of which the four presented here are the quantitatively most prominent ones.

Based on these methodological deliberations, 17 walking interviews ${ }^{2}$ were conducted on the North Frisian Islands of Sylt, Amrum and Hooge. Interview partners were contacted with the help of local and regional institutions. First, qualitative interviews were carried out centred on the topics of sense of place (Heimat), climate change and the anticipated future of the island within the time frame of the coming 30 years. At the end of each qualitative interview, interviewees were asked whether they might be willing to participate in a walking interview. These were conducted 2-8 weeks after the qualitative interviews to secure trust and intimacy generated during the first sedentary interview. All interviews were conducted in different places on the islands mentioned. Interviews lasted between 55 and $140 \mathrm{~min}$, and the same interview guide as in the sedentary interviews was used. Interviews were conducted in a sensitive and intervieweeoriented way meaning that the interview guide provided a thematic thread while attention was also drawn to aspects occurring or emerging during the walks. The aim of this procedure consisted in putting emphasis on the interaction of the interviewee with her or his spatial surroundings.

\footnotetext{
2 The sample of 17 interviewees consists of 12 men and 5 women. Their age lies between 32 and 67 with an average age of 48.5 walking interviews were conducted on Hooge, 6 on Amrum and 6 on Sylt. All interview partners are locals meaning that they were either born on the island, have family ties or actively lived there for more than 20 years.
}

\section{The North Frisian coastscape: a multifaceted amalgam $^{3}$}

As we have already alluded to in the theoretical and methodological section, our interview partners conceptualise the coastal landscape in various ways. We therefore analyse in this section the four most prevalent interpretative repertoires with the help of paradigmatic examples. We start with the aesthetic repertoire. It occurs quite frequently, and in many cases, landscape features of the Wadden, the islands and the coast are highly valued as "unique" (I9) and "outstanding" (I1). Quotes, such as the following, clearly belong to the aesthetic repertoire. They display a multi-sensuous appraisal of the North Frisian Coast that reveals and blends various features:

"I tell you something, ah, this landscape with all its colours and these smells, so typical for the mud flats.

Especially during storm, that is really breath-taking.

And this vast expanse of the Wadden Sea, that makes

me feel free and, yeah, I am really free ah, I can think

freely." (I 5)

The first aspects of note in this quote are the visual elements perceived by the interview partner. Reference to "colours" and the "vast expanse" of the Wadden Sea are made and develop an experienced visuality that pictures an immersive and stunning vastness. Such aspects also occur in other interviews in which interviewees speak of an "endless sky" (I9) or "vastness of the landscape" (I12) of the Wadden Sea. The experienced spatiality of the coastscape is articulated in relation to the own body- "we as humans are so small" (I14) - and depicts a though unconscious experience of the sublime that is on the one hand emotionally experienced as "breath-taking" during storms while it is on the other hand metaphorically connected to the individual as instigating the feeling of freedom. The coast is the stretch of land where one feels free and is surrounded by typical "salty" (I8) or muddy "smells" (I3) so constitutive for the coastal atmosphere of the Wadden Sea. Comparable aspects also occur in the following interview excerpt:

"Look here, isn't that great, this expanse? Do you need anything-else? The horizon is so low and the vista is not blocked by anything. And here, listen to the waves, they seem to be mumbling ... and [the] smell of the waves." (I14)

\footnotetext{
The aspects investigated here converge with the findings as outlined in Döring and Ratter (2018) who analysed sedentary interviews. The present study is a follow-up study based on mobile methods which exhibits in more detail the ways how the interviewees conceive themselves as enmenshed in their coastscapes.
} 
Again the visual aspects of the coastscape are foregrounded-"the horizon is so low and the vista is not blocked" - while at the same time reference is made to typical elements of the coastscape and its characteristics: Waves provide sounds ("listen to the waves"), they are personified as "mumbling" and "smelling" entities while the neat observation of the dunes including their dynamic sandy structure leads to enthusiasm as expressed in the exclamation of "fascinating!". A tendency becomes apparent to value and relate to the coastscape in aestheticized terms and by drawing on emotions such as freedom, enthusiasm as well as on elements of the sublime and beauty. What one can clearly see here is that so-called natural aspects of the coastscape are not experienced as something external, they are incorporated via the situated sensitivities of the interview partners-an aspect which has attracted attention in the Danish and Dutch, but rarely in the German Wadden Sea context.

This aspect of the relational sense of coast is complemented by the genealogical repertoire where elements of coastal landscape instigate a biographical and genealogical thinking: Backward and forward lineages are made in face of the temporality of the coastal landscape. This can be seen in the following quote where temporal insinuations are made in the interaction with the coastscape that becomes a place blending past and future into the present coastal here and now:

"Nature and the landscape here are more or less everlasting things, we are just here for a bit of their time. Although my family has been here for more than 100 years, some have left while we stayed and built our business. It was a conscious decision and we all have a strong connection with this island and this landscape. My children were born here, but both left due to the job situation. We have grandchildren now. Perhaps they come back once we are gone [...]" (I6)

What becomes apparent in the quote is the fact that different temporalities of nature and landscape are used as an intransient background that is contrasted with human temporality. The difference between these temporalities sets a time-based framework into which reflections on the history of the family are integrated. Lexical items stemming from the semantic field of family such as "daughter", "son" or "grandchildren" refer to the future while "grandfather" (I14), "grandmother" (I17) or "my parents" (I12) connote the past. These considerations develop lifecycles of families which are often depicted against the backdrop of an everlasting coastal nature. This can be seen in the following quote:

"It is like the come and go of the sea which you can see here. It has always been like this and why should it be different for us? Your parents normally leave this planet before you and you follow them before your children and your grandchildren. We all are very attached to this stretch of land and love it because our family has always been here." (I9)

Besides the interesting aspect that all family members appear to hold a strong emotional attachment to the coast, the coastscape with its changing scenery of the incoming and outgoing water and waves appears to motivate certain types genealogical reflection: the natural dynamics and the circularity of the Wadden Sea is merged with that of the interviewee's own family and suggests the idea of a temporal succession. What becomes apparent is that the individual genealogy is enmeshed with the coastscape, providing not only a socio-spatial, but also a socio-temporal grounding. Emotions of nostalgia, hope and expectation are expressed as well as-only-sometimes resignation ("Perhaps they come back once we are gone [...]", I6). Viewed conceptually, the coast and its landscape characteristics are the place where natural and individual temporalities are synchronised, providing an anchorage of individual time in the infinite time of nature.

Alongside these aspects of family genealogies and their lifecycles, the materiality of the North Frisian coast represents an interpretative reservoir which we term the resistance repertoire. This reflects resistance in two ways. First, against the sea, which is often expressed with reference to coastal defence practices and land reclamation in former times, and second against nature protection. Especially the second aspect appears now and again in conversations with older people who have actively taken part in the disputes and fights against the national park. Here, the opponents are framed by generic nouns such as "nature protection" (I14), "the greens" (I2) or "those conservationists" (I 17). Demonstratives such as "those" (I8) or "they" (I15) linguistically insert a social distance with regard to representatives of the national park. However, resistance is motivated by and articulated in many cases in relation to special and contested places, as in the following quote:

"You see that patch of land over there? These conservationists tried to tell me that I am not allowed to walk on my dune because there are certain birds that should be protected or need some quiet. This has been my path through the dunes since I was young and they will not keep me away from it - I have my walks there every day enjoying the birds, the growing plants and observing the insects. I told it to [...] and he looked at me with eyes wide open. This is my place and not theirs!" (I11)

We witness here a conflict between (a particular interpretation of) nature protection and a local inhabitant about the accessibility of the dune landscape. While the local inhabitant argues in terms of an individually historicised custom 
and practice, nature protection-in his view-refers to common law and has sought to prohibit access to the area. The emotional attachment to that stretch of coast is expressed by the various possessive pronouns depicting a sense of ownership in terms of "my coast", "my path" or "my walk". Such constructions appear quite often and articulate that it is "my coastal landscape" (I8) or more generically "we are also the Wadden Sea" (I17). This resistance against the division in protected coastal nature and an encultured nature (see Hörst in this volume) with its beaches and paths is often criticised, resulting in practices as expressed in the quote. What we see are conflicting notions of nature that arise in the coastscape which becomes a landscaped entity where resistance against a felt paternalism is bodily and verbally articulated.

Secondly, we have the aspect of resistance against the sea and its—metaphorically speaking — moods. The joint fight against the sea repertoire represents a common interpretative reservoir expressing the aspect of resistance against the "mighty enemy water" (I10). Such aspects often raised in the context of a historicised argumentation as in the following quote:

"Whenever I look at the dikes on the mainland or the coastal defence infrastructure we have here, it always reminds me of the fact that our ancestors did a great job in fighting back the sea or taming it at least. Smart and beautiful craftsmanship, I would say. I mean, we are safe here and to me they are part of the landscape. It makes me proud to stand here and see it." (I14)

Here, coastscape-related feelings of pride are ostensibly expressed in view of historical facts. The landscape and its prevalent elements of coastal defence infrastructure are understood as an integral part of the coastscape ("they are a part of the landscape") that paradigmatically stand for feistiness against the "dangerous sea" (I3), "storm surges" (I8) "floodings" (I17) "vagaries of weather" (I1): here parts of or in the coastscape and their characteristics are blended with the robustness and resilience of the inhabitants. Furthermore, the dikes in the landscape are not only perceived as a means of protection, they are also regularly walked on for example during walks (I13, I4, I9) or daily routines such as taking the dog for a stroll (I5, I15, I7). Hence, they do not only attract mindful reflection but are also integrated into practices which create the landscape and make them an experienced and bodily practiced part of it.

Finally, the coastscape is also used for constructing the interpretative identity repertoire. This aspect is often articulated in the interviews by referring to the coastal landscape and its structure as resulting from or being a product of the Frisian fight against the sea and for arable land. This has been paradigmatically expressed in the motto "God created the sea, the Frisians the coast". Although land reclamation came to a halt in the 1970s, the fight metaphor still nestles in the cultural memory of most coastal dwellers. This can for example be seen in the following interview extract:

"This landscape is human made. Without us and our ancestors, who fought against the sea, this all would not exists. It is a Frisian-made coast and this sand contains sweat, blood, tears and a lot of dead people. How goes the proverb? God made the sea - you can see there - and the Frisians - us - made this here around us, the coast." (I13)

The content of this interview segment is quite intense because it merges elements of a general regional history, the landscape, its materiality and the well-known proverb. These are drawn together to construct a Frisian identity (see also Krauß 2005; Walsh 2020). During the situated thought process, reference is made to the sand ("this sand") of the coastscape which is understood as consisting of "sweat, blood, tears and a lot of dead people" which denaturalises the coast and enhumanises it. This is, however, contrasted with a clear division between the natural enemy "sea" and "the [...] coast" which is depicted not only as Frisian-made, but substantially consisting of body parts of those who drowned.

Although examples of such a bodily embodiment of the coast are quite rare (I11 and I15), other examples taken from our corpus point to comparable aspects. Reference is, time and again, made to the already mentioned proverb (for example I1, I3, I4, I12 and I15), the landscape is depicted as Frisian as in the following quote:

"We stand here in... a cultural landscape and not a natural landscape. It has been made by the currents and the people that settled here, the Frisians. And I really identify not only with the Frisian culture, but also with this landscape here which is Frisian to me, you know? Somehow it is historically but also emotionally a part of me." (I7)

The reference in this quote raises more general aspects but its start is quite remarkable: The distinction between a cultural and a natural landscape and the emphasis put on the former one establishes a conceptual framework against which the construction of a Frisian identity is carried outthis revitalisation and essentialisation of a Frisian identity in view of landscape has also been shown by Krauss (2005) in his study on the disputes revolving around the implementation of Natural Word Heritage in the North Frisian Wadden Sea. The generic phrase "Frisian culture" and the landscape with its history are drawn together resulting in an emotional and embodied ("part of me") relationship. Again, the body is landscaped into the coast and the coast is landscaped into the body. Both quotes display a reconstruction of a mythologised past framing the North Frisian coastscape as the continuous fight between the Frisians and the sea. This is also 
expressed by the often-occurring notion of "home" (8), "this coast is my home" (I5) or "coastal home" (I13).

In summary, one can say that the North Frisian Wadden Sea coast represents multiple social, temporal and spatial constructions as illustrated by the interpretative repertoires. These provide a multifaceted and deep insight into what the North Frisia coast stands for: it embodies the elements experienced, it is based on shifting boundaries drawn between nature and culture (see Hörst in this volume, Walsh 2018, 2020) and it refers to a Frisian identity that is landscaped into the present coast. Theoretically seen, these aspects of an embodied landscaping are based on the process of a relational experiencing, enwalking and enlanguaged knowing of the North Frisian coastscape bringing about a more-than representational perspective which we termed the coastmultiple (Döring and Ratter 2018).

\section{A more-than-representational and multiple understanding of the North Frisian coast}

The previous section has provided empirical insights into the various relational patterns and dimensions coastal dwellers in North Frisia form with their coastscapes (Crouch 2010). To conceptualise this relation, the convergences of a relational and more-than-representational perspective (Thrift 1996: 1-50) on coastscapes enabled us to theoretically understand and empirically reveal how the ontological materialities of the North Frisian coast interact with and are informed by the multisensuous and sometimes intangible associations its coastal dwellers develop with their surrounding coastscapes. The interpretative repertoires made accessible through the mobile, embodied and emplaced method of walking interviews offered a vital, experiential and systematised insight into how not only the visual, but also smells, textures, tastes and sounds draw coastal dwellers and the coastscape together. What became apparent is that meaning-making occurs in action and interaction (Waterton 2019: 93), and it exhibits a detailed and creative involvement which can be revealed by walking interviews and analysed with the help of situated language games. The integrative understanding of the analytical units of landscape and language as analysed here is based on the insight that languaging (Love 2017) and language games knit - to follow Ingold's (2007) thread and line heuristicmore-than-representational and relational patterns into coastal landscapes that go well beyond the dichotomy nature $=$ sea/ shore and culture $=$ coastal landscape (Descola 2003).

Furthermore, the theoretical extension of more-thanhuman approaches in geography as based on a more-thanin-the-head-understanding of language (Steffensen 2009) proved to be useful as linguistic meanings evolve in, and are articulated and stabilised by socio-temporal language games in places and landscapes: Spatial experiences and linguistic meanings interlace coastal inhabitants with their dwelt-in coastscape in manifold ways of meaningful immersion, emplaced intimacy and experienced materiality resulting in landscaped relationalities. Thus, coasts should be understood as hybrid entities (Latour 1993) that assemble and display various modes of socio-natural existences (Latour 2018) or nature-society-mixes (Hinchliffe and Woodward 2004: 153-158): the coast multiplies depending on experiences and practices (Mol 2003:4). The coast is, as we have seen, spoken, felt and experienced into existence(s) and these dimensions appear to be important ingredients in social shoreline conflicts (Thompson 2007) which have so far seldom been addressed on the German Wadden Sea coast. Here, more-than-representational ways of knowing and experiencing coastal spaces, places and landscapes (Yeh 2015) hold the potential to inspire future management (Whatmore 2013) shifting emphasis away from a purely science-informed understanding of the coast by redistributing expertise and symmetrising the social roles of those involved as apprentices to the topic under scrutiny (Whatmore and Landström 2011). The insight that the coast is multiple is just a start, but perhaps an entry point to manage the Wadden Sea coastscape in a more interactive and integrated way.

Acknowledgements We would like to thank Brigitte Nerlich (Nottingham) and Cormac Walsh (Hamburg) for the valuable comments on earlier versions of this paper. The same goes to the two anonymous reviewers who have helped us to considerably improve the many aspects addressed here.

Author contribution Not applicable.

Funding Open Access funding enabled and organized by Projekt DEAL. This research has been financed by the Helmholtz Initiative REKLIM (Regional Climate Change) and was conducted within the working group 7 "Risk analysis and risk management for integrated climate strategies".

Data availability Not applicable.

Code availability Not applicable.

\section{Declarations}

Conflict of interest The authors declare no competing interests.

Open Access This article is licensed under a Creative Commons Attribution 4.0 International License, which permits use, sharing, adaptation, distribution and reproduction in any medium or format, as long as you give appropriate credit to the original author(s) and the source, provide a link to the Creative Commons licence, and indicate if changes were made. The images or other third party material in this article are included in the article's Creative Commons licence, unless indicated otherwise in a credit line to the material. If material is not included in the article's Creative Commons licence and your intended use is not permitted by statutory regulation or exceeds the permitted use, you will need to obtain permission directly from the copyright holder. To view a copy of this licence, visit http://creativecommons.org/licenses/by/4.0/. 


\section{References}

Anderson, Ben, and Paul Harrison, eds. 2010. Taking place. Nonrepresentational theories and geography. London: Routledge.

Anderson, Jon. 2000. Talking whilst walking: A geographical archaeology of knowledge. Area 36: 254-261.

Austin, John. 1962. How to do things with words: The William James Lectures delivered at Harvard University Press. Oxford: Clarendon Press.

Bang, Jørgen., and Wilhelm Trampe. 2014. Aspects of an ecological theory of language. Language Sciences 41: 83-92.

Basso, Keith. 1996. Wisdom sits in places: Landscape and language among the Western Apache. Albuquerque: University of New Mexico Press.

Bender, Barbara, ed. 1993. Landscape: Politics and Perspectives. Oxford: Berg.

Black, Max. 1993. More about metaphor. In Metaphor and Thought, ed. Andrew Ortony, 19-43. Cambridge: Cambridge University Press.

Boissevain, Jeremy, and Tom Selwyn, eds. 2004. Contesting the foreshore: Tourism, society and the politics on the coast. Amsterdam: Amsterdam University Press.

Brace, Catherine, and Hilary Geoghegan. 2010. Human geographies of climate change: Landscape, temporality, and lay knowledges. Progress in Human Geography 35: 284-302.

Castree, Noel. 2005. Nature. London: Routledge.

Castree, Noel. 2014. Making sense of nature. London: Routledge.

Corbin, Alain. 1995. The lure of the sea: Discovery of the seaside. London: Penguin.

Corbin, Juliet, and Anselm Strauss. 2015. Basics of qualitative research: Techniques of procedures for developing grounded theory. London: Sage.

Cosgrove, Denis. 1988. Social formation and Symbolic landscape. Madison: University of Wisconsin Press.

Cosgrove, Denis, and Stephen Daniels, eds. 1988. The iconography of landscape: Essays on the symbolic representation, design and use of past environments. Cambridge: Cambridge University Press.

Cowley, Stephen, ed. 2011. Distributed language. Amsterdam: John Benjamins.

Cowley, Stephen. 2019. The return of languaging. Chinese Semiotic Studies 15: 483-512.

Crouch, David. 2010. Flirting with space: Thinking landscape relationally. Cultural Geographies 17: 5-18.

Descola, Philippe. 2003. Beyond nature and culture. Chicago: University of Chicago Press.

deSilvey, Caitlin. 2012. Making sense of transience: An anticipatory history. Cultural Geographies 19: 31-54.

Dewsbury, John-David. 2003. Witnessing space: Knowledge without contemplation. Environment and Planning c: Society and Space 18: 473-496.

Dewsbury, John-David., John Wylie, Paul Harrison, and Mitch Rose. 2002. Enacting geographies. Geoforum 32: 437-441.

Döring, Martin, Wolfgang Settekorn, and Hans von Storch, eds. 2005. Küstenbilder, Bilder der Küste. Interdisziplinäre Ansichten, Ansätze und Konzepte. Hamburg: Hamburg University Press.

Döring, Martin, and Beate Ratter. 2018. Coastal landscapes: The relevance of researching coastscapes for managing coastal change in North Frisia. Area 50: 169-176.

Egberts, Linde, and Meindert Schoor, eds. 2018. Waddenland outstanding. History, landscape and cultural heritage of the Wadden Sea region. Amsterdam: Amsterdam University Press.

Fischer, Ludwig, ed. 1997. Kulturlandschaft Nordseemarschen. Westerhever: Hever Verlag.
Fischer, Norbert, Susann Müller-Wusterwitz, and Brigitte SchmidtLauber, eds. 2007. Inszenierungen der Küste. Berlin: Reimer.

Gesing, Friederike. 2016. Working with nature un Aotearoa New Zeeland. An ethnography of coastal protection. Bielefeld: Transcript.

Gibson, James. 1979. The ecological approach to visual perception. London: Routledge.

Gillis, John. 2014. The human shore: Seacoasts in history. Chicago: University of Chicago Press.

Gros, Frédéric. 2011. Marcher: Une philosophie. Paris: Flammarion.

Hansen, Andreas Skriver. 2021. Understanding recreational landscapes - a review and discussion. Landscape Research 46: 128-141.

Harré, Rom, Jens Brockmeier, and Peter Mühlhäusler. 1999. Greenspeak. A study in environmental discourse. London: Sage.

Harrison, Paul. 2000. Making sense: Embodiment and the sensibilities of the everyday. Environment and Planning d: Society and Space 18: 497-517.

Hasse, Jürgen. 2014. Was Räume mit uns machen - und wir mit ihnen: Kritische Phänomenologie des Raumes. Freiburg: Karl Alber.

Hasse, Jürgen. 2016. Versunkene Seelen: Begräbnisplätze ertrunkener Seeleute im 19. Freiburg: Jahrhundert. Karl Alber.

Hasse, Jürgen. 2017. Die Aura des Einfachen: Mikrologien des räumlichen Erlebens. Freiburg: Karl Alber.

Hinchliffe, Steve, and Kath Woodward. 2004. Afterword. In The natural and the social: Uncertainty, risk, change, ed. Steve Hinchliffe and Kath Woodward, 153-158. London: Routledge.

Holzhausen, Jessica, and Kevin Grecksch. 2021. Historic narratives, myths and human behavior in times of climate change: A review from northern Europe's coastlands. Wire's Climate Change. https://doi.org/10.1002/wcc.723.

Howard, Peter, Ian Thompson, Emma Waterton, and Mick Atha, eds. 2019. The Routledge Companion to Landscape Studies. London: Routledge.

Hulme, Mike. 2016. Weathered: Cultures of climate. London: Sage.

Hutton, Daniel. 2013. Enactivism, from a Wittgensteinian point of view. American Philosophical Quarterly 50: 281-302.

Ingold, Tim. 2000. Perception of the environment: Essays in livelihood, dwelling and skill. London: Routledge.

Ingold, Tim. 2007. Lines: A brief history. London: Routledge.

Ingold, Tim. 2008. Bindings against boundaries: Entanglements of life in an open world. Environment and Planning A 40: 1796-1810.

Johnson, Mark. 1987. The body in the mind: The bodily basis of meaning, imagination, and reason. Chicago: Chicago University Press.

Jones, Phil, Griff Bunce, James Evans, Hannah Gibbs, and Jane Ricketts Hein. 2008. Exploring space and place with walking interviews. Journal of Research Practice 4: 1-9.

King, Alexandra, and Jessica Woodroffe. 2017. Walking Interviews. In Handbook of research methods in health social sciences, ed. Pranee Liamputtong, 1-22. New York: Springer.

Köpsel, Vera, Cormac Walsh, and Catherine Leyshon. 2017. Landscape narratives in practice: Implications for climate change adaptation. Geographical Journal 183: 175-186.

Krauß, Werner. 2005. The Natural and cultural landscape heritage in Northern Friesland. International Journal of Heritage Studies 11: 39-52.

Kusenbach, Margarete. 2004. Street phenomenology: The go-along as ethnographic research tool. Ethnography 3: 455-485.

Land, Isaac. 2007. Tidal waves: The new coastal history. Journal of Social History 40: 731-743.

Lakoff, George, and Mark Johnson. 1980. Metaphors we live by. Chicago: University of Chicago Press.

Latour, Bruno. 1993. We have never been modern. Cambridge: Cambridge University Press.

Latour, Bruno. 2007. Reassembling the social: An introduction to actor-network theory. Oxford: Oxford University Press. 
Latour, Bruno. 2018. An inquiry into modes of existence: An anthropology of the moderns. Harvard: Harvard University Press.

Lençek, Lena, and Gideon Bosker. 1999. The beach: A history of paradise on earth. London: Pimlico.

Leyshon, Catherine. 2018. Finding the coats: Environmental governance and the characterisation of land and sea. Area 50: 150-158.

Lorimer, Hayden. 2005. Cultural geography: The busyness of being more-than-representational. Progress in Human Geography 29: 83-94.

Love, Nigel. 2017. On languaging and language. Language Sciences 61: 1-35.

Macpherson, Hannah. 2006. Landscape's ocular centrism - and beyond? In From landscape research to landscape planning: Aspects of integration, education and application, ed. Bärbel. Tress and Gunther Tress, 95-104. Dordrecht: Springer.

Macpherson, Hannah. 2010. Non-representational approaches to bodylandscape relations. Geography Compass 4: 1-13.

Macpherson, Hannah. 2016. Walking methods in landscape research: Moving bodies, spaces of disclosure and rapport. Landscape Research 41: 425-432.

Matless, David. 2001. Landscape and Englishness. London: Reaction Books.

Medby, Ingrid. 2019. Language-games, geography, and making sense of the Arctic. Geoforum 107: 124-133.

Mels, Tom, and Gunhild Setten. 2007. Romance, practice and substantiveness: What do landscapes do? Geografisker Annaler Series B - Human Geography 89: 197-202.

Mol, Annemarie. 2003. The body multiple: Ontology in medical practice. Durham: Duke University Press.

Moles, Kate. 2008. A walk in third space: Place, methods and walking. Sociological Research Online 13: 1-8.

O'Neil, Maggie, and Brian Roberts, eds. 2019. Walking methods. Research on the move. London: Routledge.

Pearson, Michael. 2006. Littoral society: The concept and the problems. Journal of World History 17: 353-373.

Pile, Steve. 2010. Emotions and affect in recent human geography. Transactions of the Institute of British Geographers 35: 5-20.

Ratter, Beate and Catherine Leyshon. 2021. Perceptions of and Resilience to Coastal Climate Risks. Oxford Research Encyclopedia of Climate Science. https://oxfordre.com/climatescience/ view/https://doi.org/10.1093/acrefore/9780190228620.001.0001/ acrefore-9780190228620-e-819. Accessed 28 April 2021

Ratter, Beate, and Cormac Walsh. 2019. Küstenlandschaften. In Handbuch Landschaft, ed. Olaf Kühne, Florian Weber, Karsten Berr, and Corinna Jenal, 699-710. Wiesbaden: Springer Verlag.

Ritson, Katie. 2018. The shifting sands of the North Sea Lowlands. London: Routledge.

Robertson, Ian, and Penny Richards. 2003. Introduction. In Studying Cultural Landscapes, ed. Ian Robertson and Penny Richards, 1-13. London: Hodder and Stoughton.

Rodaway, Paul. 1994. Sensuous Geographies. Body Sense and Place. London: Routledge.

Rose, Mitch, and John Wylie. 2006. Animating landscape. Environment and Planning D 24: 475-479.

Ryan, Anna. 2012. Where land meets sea. Coastal explorations of landscape, representation and spatial experience. London: Routledge.

Seamon, David. 2018. Life takes place. Phenomenology, lifeworlds, and place making. London: Routledge.

Sheller, Mimi, and John Urry. 2006. The new mobilities paradigm. Environmental and Planning A 38: 207-226.

Spinggay, Stephanie, and Sarah Truman. 2019. Walking methodologies in a more-than-human world: Walkinglab. London: Routledge.

Steffensen, Sune Vork. 2009. Language, languaging, and the extended mind hypothesis. Pragmatics and Cognition 17: 677-697.
Steffensen, Sune Vork, and Alwin Fill. 2014. Ecolinguistics: State of the art and future horizons. Language Science 41: 6-25.

Stenseke, Marie. 2018. Connecting relational values and relational landscape approaches. Current Opinion in Environmental Sustainability 35: 82-88.

Süsswein, Noah, and Timothy Racine. 2009. Wittgenstein and not-justin-the-head cognition. New Ideas in Psychology 27: 184-196.

Thrift, Nigel. 1996. Spatial Formations. London: Sage.

Thrift, Nigel. 1999. Steps to an ecology of place. In Human geography today, ed. Doreen Massey, John Allen, and Phil Sarre, 295-321. Cambridge: Polity Press.

Thrift, Nigel. 2000. Afterwords. Environment and Planning d: Society and Space 18: 213-255.

Thrift, Nigel. 2004. Intensities of feeling: The spatial politics of affect. Geografisker Annaler Series B 86: 57-78.

Thrift, Nigel. 2007. Non-representational theory. London: Routledge.

Thompson, Robert. 2007. Cultural models and shoreline social conflict. Coastal Management 25: 211-237.

Vannini, Philippe, ed. 2015. Non-representational methodologies: Reenvisioning research. London: Routledge.

Vannini, Philipp, and Jonathan Taggart. 2012. Doing islandness: A non-representational approach to and island's sense of place. Cultural Geographies 20: 225-242.

Varela, Francisco, Evan Thompson, and Eleanor Rosch. 1991. The embodied mind Cognitive science and human experience. Cambridge: MIT Press.

Vincenzotti, Vera, Anna Jorgensen, Mattias Quistrom, and Simon Swaffield. 2016. Forty years of Landscape Research. Landscape Research 41: 388-407.

Visser, Leontine, ed. 2004. Challenging coasts. Transdisciplinary excursions into integrated coastal zone management. Amsterdam: Amsterdam University Press.

Walsh, Cormac. 2018. Metageographies of coastal management: Negotiating spaces of nature and culture at the Wadden Sea. Area 50: $177-185$.

Walsh, Cormac. 2020. Landscape imaginaries and the protection of dynamic nature at the Wadden Sea. Rural Landscapes: Society, Environment, History 7.https://doi.org/10.16993/rl.55

Walsh, Cormac. 2021. Zwischen, Ruhe " und, Unberührtheit': Landschaftsbilder am Wattenmeer im internationalen Vergleich. In Landschaftsbilder und Landschaftsverständnisse in Politik und Praxis, ed. Cormac Walsh, Gisela Kangler, and Markus Schaffert, 33-58. Wiesbaden: Springer VS.

Walsh, Cormac, and Martin Döring. 2018. Cultural geographies of coastal change. Area 50: 146-149.

Warnke, Martin. 2004. Political landscape: The art history of nature. London: Reaction Books.

Waterton, Emma. 2019. More-than-representational-landscapes. In The Routledge Companion to Landscape Studies, ed. Peter Howard, Ian Thompson, Emma Waterton, and Mick Atha, 91-101. London: Routledge.

Whatmore, Sarah. 2013. Earthly powers and affective environments: An ontological politics of flood risk. Theory, Culture and Society 30: $30-50$.

Whatmore, Sarah, and Catharina Landström. 2011. Flood apprentices: An exercise in making things public. Economy and Society 40: 582-610.

Whetherell, Margaret, and Jonathan Potter. 1988. Discourse and the identification of interpretative repertoires. In Analysing Everyday Explanation: A casebook of methods, ed. Charles Antaki, 168-183. London: Sage.

Wittgenstein, Ludwig. 2009. Philosophical investigations. Chichester: Blackwell.

Worthington, David, ed. 2017. The new coastal history. Cultural and environmental perspectives from Scotland and beyond. Basingstoke: Palgrave. 
Wylie, John. 2002. An essay on ascending Glastonbury Tor. Geoforum 33: 441-454.

Wylie, John. 2005. A single's day walking: Narrating self and landscape on the South West Coastal Path. Transactions of the Institute of British Geographers 30: 234-247.

Wylie, John. 2007. Landscape. London: Routledge.
Yeh, Emily. 2015. How can experience of local residents be 'knowledge'? Challenges in interdisciplinary climate change research. Area 49: 34-40.

Publisher's note Springer Nature remains neutral with regard to jurisdictional claims in published maps and institutional affiliations. 